\title{
Graft vasculopathy in a Wistar rat model of heterotopic heart transplantation depending on gender matching between donors and recipients
}

\author{
Joanna E Śliwka ${ }^{1}$, Roman Przybylski ${ }^{1}$, Anna Dołaszyńska-Żółkiewska², Adam Sokal ${ }^{3}$, Mirosław Tyrpieńn $^{4}$, \\ Piotr M. Wilczek ${ }^{5}$, Marian Zembala ${ }^{1}$ \\ ${ }^{1}$ Department of Cardiac, Vascular and Endovascular Surgery and Transplantology, Silesian Center for Heart Diseases, \\ Medical University of Silesia, Zabrze, Poland \\ $24^{\text {th }}$ City Hospital, Department of General Surgery, Gliwice, Poland \\ ${ }^{3}$ Department of Cardiology, Silesian Center for Heart Diseases, Medical University of Silesia, Zabrze, Poland \\ ${ }^{4}$ Department of Environmental Medicine and Epidemiology, Medical University of Silesia, Zabrze, Poland \\ ${ }^{5}$ Foundation for Cardiac Surgery Development, Zabrze, Poland
}

Kardiochirurgia i Torakochirurgia Polska 2018; 15 (3): 157-161

\begin{abstract}
Introduction: Heart transplant is an accepted treatment modality in end-stage heart failure. The graft coronary artery vasculopathy is a main concern to explain the heterogeneity of the rejection process according to the gender of the donor and recipient.

Aim: To assess the severity and type of mechanisms leading to failure of the graft.

Material and methods: Experimental allogenic heart transplantation in the abdomen was performed on Wistar rats depending on the gender of the donor and recipient ( $\mathrm{F}$ - female; $M$ - male) in four groups (FF, FM, MM MF). The donor heart was implanted in the abdominal cavity of the recipient. Complete time of observation was 10 weeks. Bromodeoxyuridine was administered intraperitoneally to detect proliferating cells. Results: There was $42.5 \%$ graft survival in all experiments. The mean time of graft survival was $60 \pm 18,54 \pm 29,58 \pm 23$ and 64 \pm 18 days (FF, FM, MM and MF) and no significant difference was found in graft survival time among the four experimental groups $(p=0.73)$. None of the heart weight changes reached statistical significance.

Conclusions: The use of an animal experimental model helps to understand the mechanisms leading to graft failure and to compare the changes that occur in rats to human hearts. The gender matching affects the survival of the transplanted heart and severity of the graft vasculopathy.
\end{abstract}

Key words: heart transplantation, gender match, animal model.

\section{Streszczenie}

Wstęp: Transplantacja serca jest uznaną metodą postępowania w krańcowym stadium kardiomiopatii o różnej etiologii, niewydolności oraz nieoperacyjnych wad wrodzonych serca. Choroba naczyń wieńcowych serca przeszczepionego stanowi główną przyczynę upośledzenia funkcji narządu. Zwraca uwagę niejednolitość przebiegu tego procesu w zależności od płci dawcy i biorcy.

Cel: Ocena nasilenia i przyczyn niewydolności przeszczepionego serca.

Materiał i metody: Zabieg dobrzusznego wszczepienia serca wykonywano w zależności od płci dawcy i biorcy (samica - F, samiec - M) w czterech grupach (FF, FM, MM MF). Okres obserwacji wynosit 10 tygodni. Podano dootrzewnowo bromodeoksyurydynę (BrdU) w celu wykrycia komórek proliferujących. Wyniki: Przeżywalność przeszczepionego narządu w eksperymencie wynosiła $42,5 \%$. Średni czas przeżycia narządu wynosił $60 \pm 18,54 \pm 2958 \pm 23$ oraz $64 \pm 18$ dni, odpowiednio dla grup FF, FM, MM oraz MF. Nie stwierdzono istotnych statystycznie różnic pomiędzy grupami w zakresie długości przeżycia narządu $(p=0,73)$. W żadnej grupie różnice masy narządu nie uzyskały istotności statystycznej.

Wnioski: Zastosowanie modelu zwierzęcego pozwala zrozumieć mechanizmy prowadzące do niewydolności przeszczepionego narządu oraz odnieść zmiany zachodzące u szczurów do zmian występujących u ludzi. Dobór płci dawcy i biorcy wpływa na przeżywalność przeszczepionego narządu i nasilenie choroby naczyń wieńcowych przeszczepu.

Słowa kluczowe: przeszczep serca, dobór płci, model zwierzęcy.

\footnotetext{
Address for correspondence: Joanna E. Śliwka, Department of Cardiac, Vascular and Endovascular Surgery and Transplantology, Silesian Center for Heart Diseases, Medical University of Silesia, 9 M. Skłodowskiej-Curie St, 41-800 Zabrze, Poland, phone: +48 501324 251, e-mail: jsliwka@sccs.pl Received: 6.04.2018, accepted: 23.07.2018.
} 


\section{Introduction}

Heart transplant is an accepted treatment modality in the end stage of any cardiomyopathy, heart failure, or uncorrectable congenital heart disease. About 30\% of transplanted heart failures depend on the process of different types of rejection in which the most important and unpredicted is allograft vasculopathy, finally leading to its failure. In clinical practice, there is no assumption that organs from male and female donors have inherent differences affecting long-term outcomes. However, data suggest that there are important differences that must be taken into account.

Regitz-Zagrosek et al. [1] in 2010 published a summary and essentials about the differences in pathology of heart failure and myocardial hypertrophy and the mechanism of its protection depending on the sex. There were genes related to energy metabolism, calcium handling and the expression and activity of nitric oxide synthases that affect heart failure. Matching the donor with the recipient does not include the gender, although there is evidence that gender of donors and recipients is involved in the process of rejection. Therefore, gender issues in transplantology should be investigated.

Using an experimental animal model allows one to understand the mechanism and progress of the rejection process and introduction of new methods of pharmacological inhibition of either severe or chronic graft rejection. Heterotopic abdominal heart transplantation first described by Ono and Lindsey is a method of choice in transplantology research. This is a model of the unloaded left ventricle with selective perfusion of the coronary arteries and also unfortunately high risk of involution of the left ventricle. To avoid involution several modifications of the model were introduced, as well as aortic regurgitation [2].

\section{Aim}

The aim of this study was to assess the severity and possible type of mechanisms leading to failure of the graft in four groups of sex-matched donors and recipients.

\section{Material and methods}

All the procedures were performed in accordance with the principles of laboratory animal care according to the
Polish Law on Animal Experiments and the animals were maintained following the guidelines, with the permission of the local Ethics Committee.

The heterotopic, abdominal heart transplant was performed according to the previously published Ono and Lindsey method [3] with author's modification.

Experimental allogenic heterotopic heart transplantation in the abdomen was performed in inbred Wistar rats weighing 250 to $450 \mathrm{~g}$ used both as donors and recipients. The animals were kept under standard conditions. Fortyeight hours before the procedure rats were limited in food access. Smaller rats served as donors for the bigger rats to match the abdominal aorta and vein anastomoses. All the procedures were performed with the use of a Wild M691 (Leica) microscope (Fig. 1).

After induction of general anesthesia with pentobarbital ( $4.5 \mathrm{mg} / 100 \mathrm{~g}$ body weight) and confirmation of the abolition of the reflexes of the donor $1 \mathrm{ml}$ of heparin was administered intraperitoneally (Heparinum, Polfa Warszawa, $5000 \mathrm{j} / \mathrm{ml}$ ). After $30 \mathrm{~min}$ sternotomy was performed. The donor heart was arrested by direct injection of $30 \mathrm{ml}$ of cold $\left(4^{\circ} \mathrm{C}\right)$ high-potassium cardioplegia (Plegisol, Abbott Laboratories) to the descending aorta, harvested and then placed directly into cold saline for $10 \mathrm{~min}$. Before implantation our own modification of the model was performed - one of the aortic leaflets was excised in order to fill the ventricle with blood, increasing contractility and postponing its involution process.

The recipient was anesthetized with the same method, placed in a supine position, the abdomen was opened and the abdominal aorta and vena cava inferior were exposed. The vessels were partially clamped and the vascular anastomoses were made with continuous sutures: end-to-side donor ascending aorta to recipient abdominal aorta just below the renal arteries (Prolene 8-0), then end-to-side donor pulmonary artery to the recipient vena cava inferior (Monosof, 10-0). Total time of ischemia was no longer than $40 \mathrm{~min}$. After declamping of the abdominal vessels, the heart rate returned spontaneously and the organ became pink in color. The abdominal wall and the skin were then closed in a standard manner. Each procedure was completed within 70 min. After surgery, the recipient recovered spontaneously and

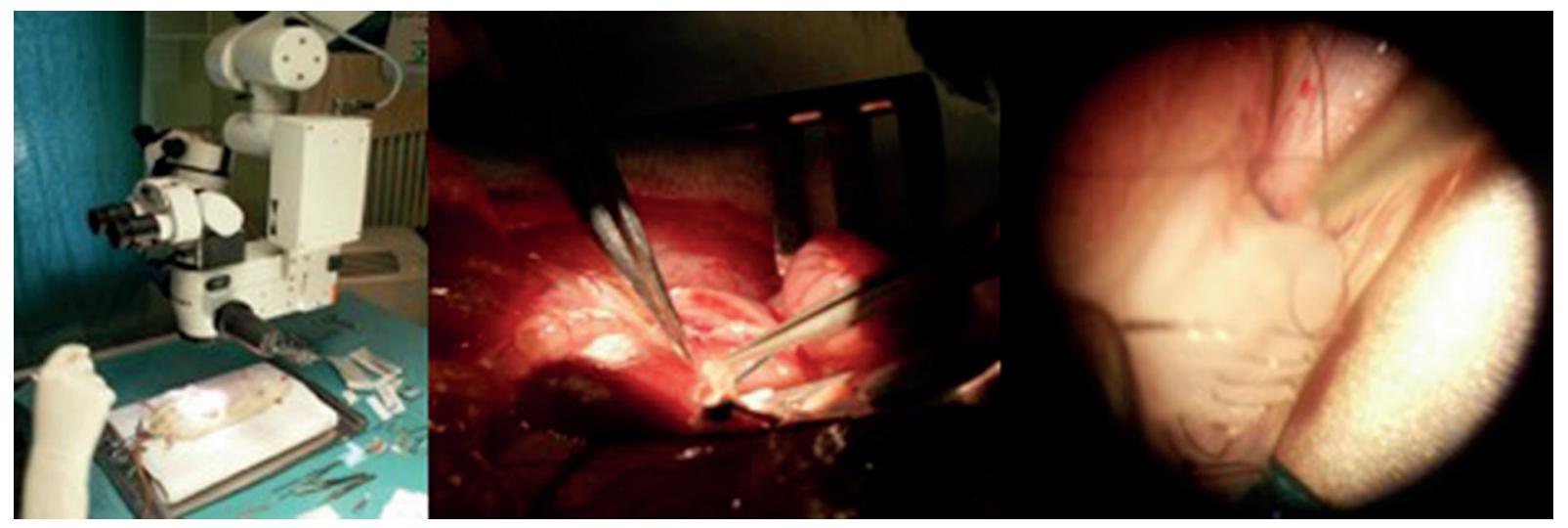

Fig. 1. The procedure was performed with the use of a Wild M691 (Leica) microscope 
received neither further post-operative medication (other than painkillers) nor immunosuppressants. We performed 40 procedures of heart transplantation in four groups ( $n=$ 10 in each group) depending on the gender of the donor and recipient: ( $F$ - female; $M-$ male) FF, MF, FM and $M M$. The viability of the transplanted heart was assessed every three days by palpation through the abdominal wall. In this model, when the heart is acutely rejected, there is an abrupt reduction in the graft pulsation amplitude, completely ceasing to beat in a few days. At the same time the graft turgor and size increase, and adhesions and mild ascites appear. The changes of chronic rejection are more subtle: the heart rate becomes irregular and decreases, the intensity of pulsation reduces linearly and the heart size diminishes [4]. Palpation of the recipient's abdomen has been a reliable method to determine the time of the rejection. The individual semiquantitative scale was assessed, as previously reported by Gordon in 2007 [5]. The rejection day definition became the time-point when no graft pulsation was palpable. In this model animal death before day 2 after transplantation was considered a technical failure. Long-term survival was confirmed when the graft was viable over the whole time of observation. Observation was discontinued 10 weeks after transplantation, the animals underwent euthanasia and heart allografts were harvested. Transplanted hearts were weighed twice, the first time when harvested from the donor before implantation to the recipient, and the second time immediately after excision, to obtain the initial and final wet heart weight. Hearts were gently blotted dry, placed in a preweighed Petri dish, and weighed on an analytical balance. At 12 and $18 \mathrm{~h}$ before heart harvesting bromodeoxyuridine (BrdU) was administered intraperitoneally to distinguish DNA synthesizing cells.

\section{Histology}

Hearts were perfused with $200 \mathrm{ml}$ of $1 \%$ buffered formalin, embedded in paraffin, sectioned, and stained with hematoxylin and eosin $(\mathrm{H}+\mathrm{E})$ using standard techniques. The application of monoclonal antibodies reacting specifically with BrdU was performed with a standard immunohistochemical assay. Grading was done by a pathologist in a blinded fashion.

\section{Statistical analysis}

Data analyses were performed with Statistica software and are expressed as means \pm standard deviation (SD); the graft survival times were analyzed using the univariate ANOVA test for multiple groups. A probability value of less than 0.05 was considered to be significant.

\section{Results}

The planned follow-up of 10 weeks was completed for $87.5 \%$ of all 4 experimental subgroups. There was $42.5 \%$ graft survival in all experiments. The mean time of graft survival was $60 \pm 18,54 \pm 2958 \pm 23$ and $64 \pm 18$ days (FF, $F M, M M$ and MF) and no significant difference was found in graft survival time among the four experimental groups

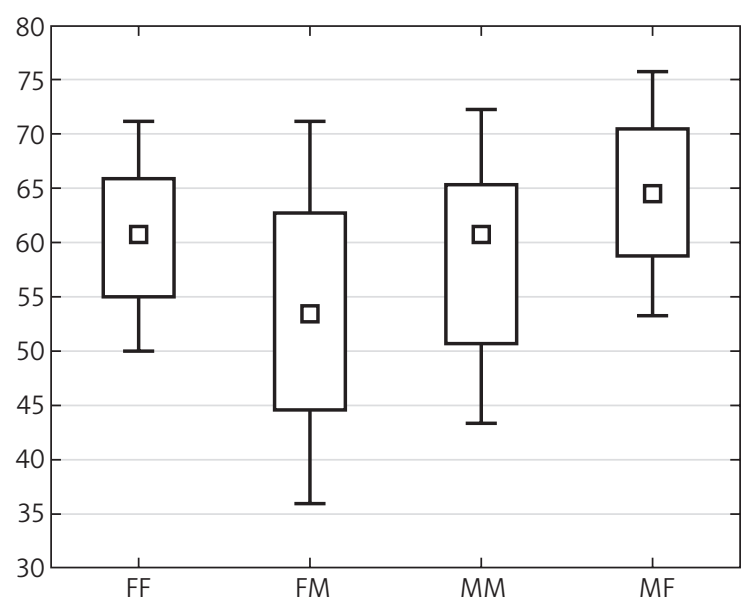

Fig. 2. Mean time of graft survival

( $p=0.73$ ) (Fig. 2). The mean graft survival time in MF was higher, but this difference was also not statistically significant. A change in the average donor heart weight between the time of transplantation and the point of explantation was observed in all groups. The mean weights of male donor hearts (MM and MF groups) were $1.36 \pm 0.18 \mathrm{~g}$ and $1.5 \pm 0.16 \mathrm{~g}$ and were higher than the respective female donor heart weights (FF and FM group): $1.02 \pm 0.1 \mathrm{~g}$ and 1.01 $\pm 0.33 \mathrm{~g}$. We observed an increase in the heart weight in female donors ( $+17 \%$ in FF and $+34 \%$ in FM) and more frequent atrophy in the MF group (-34\%). There was a subtle change in heart weight in the MM group $(-1 \%)$. None of the heart weight changes reached statistical significance (Table I).

The recipient animals gained weight during the followup period from mean $295 \mathrm{~g}$ to $360 \mathrm{~g}$ at the time of sacrifice.

Histopathology evaluation was performed twice for each animal. The presence of necrosis, mononuclear cell infiltration, fibrosis, calcifications, and vasculopathy was classified as positive (Figs. 3, 4). The degree of infiltration and arterial intimal thickening were more intense in the FM subgroup. The inner surface of most of vessels in this subgroup was irregular. The difference in percentage of positive results (50\%, 100\%, 85,7\% and 75\%) was not statistically significant for FF, FM, MM and MF subgroups, respectively. There was no difference between the different subgroups of male or female donors or recipients in cardiac allograft vasculopathy.

In the heart model, when the graft is acutely rejected, there is an abrupt reduction in the graft pulsation amplitude, and it completely ceases to beat within a few days.

At the same time, the graft turgor and size increase, and adhesions and mild ascites generally appear (Fig. 1). On the other hand, the changes of chronic rejection are more subtle: the heart rate becomes irregular and decreases, the intensity of pulsation decreases linearly, and the heart size diminishes.

\section{Discussion}

Although the surgical procedure does not differ between sexes the suspected gender-specific differences in 
Table I. Results of the study

\begin{tabular}{|c|c|c|c|c|c|}
\hline \multirow[t]{2}{*}{ Parameter } & \multicolumn{2}{|c|}{ Female donor } & \multicolumn{2}{|c|}{ Male donor } & \multirow[t]{2}{*}{$P$-value } \\
\hline & FF & FM & MM & MF & \\
\hline Mean time of graft survival [days] & $60 \pm 18$ & $54 \pm 29$ & $58 \pm 23$ & $64 \pm 18$ & 0.73 \\
\hline \multicolumn{6}{|l|}{ Graft weight change: } \\
\hline Preop. [g] & $1.02 \pm 0.1$ & $1.01 \pm 0.33$ & $1.36 \pm 0.18$ & $1.5 \pm 0.16$ & $\mathrm{n} / \mathrm{a}$ \\
\hline$\%$ change & +17 & +34 & -1 & -34 & $\mathrm{n} / \mathrm{a}$ \\
\hline Positive results in histopathology [\%] & 50 & 100 & 87.5 & 75 & $\mathrm{n} / \mathrm{a}$ \\
\hline \multicolumn{6}{|l|}{ Recipient body weight [g]: } \\
\hline Preop. & 276 & 390 & 388 & 274 & $\mathrm{n} / \mathrm{a}$ \\
\hline Postop. & 266 & 400 & 413 & 256 & $\mathrm{n} / \mathrm{a}$ \\
\hline
\end{tabular}

n/a - not applicable.

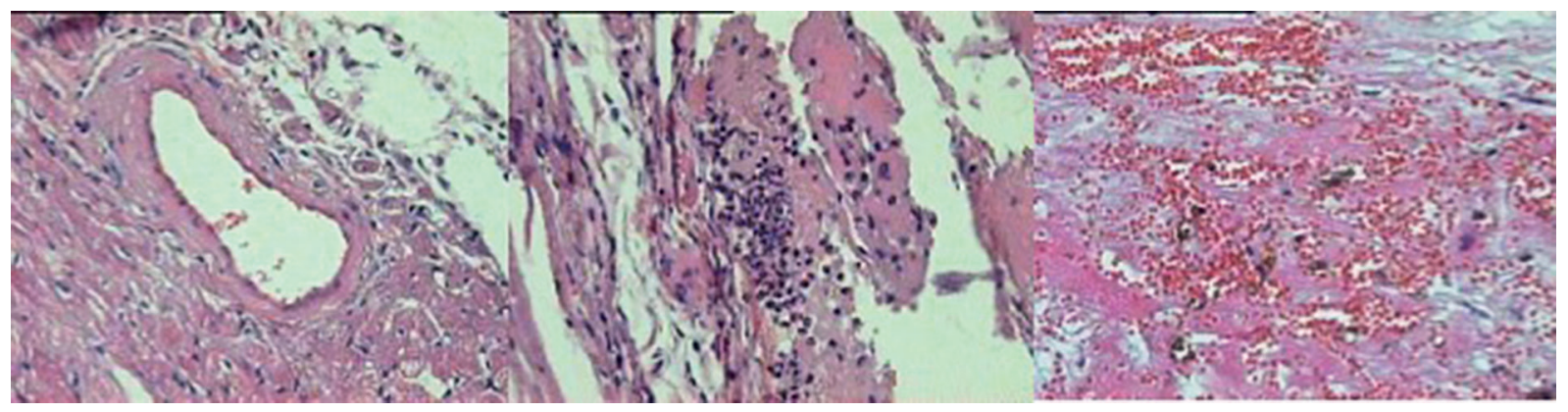

Fig. 3. Presence of necrosis, mononuclear cell infiltration, fibrosis, calcifications, and vasculopathy

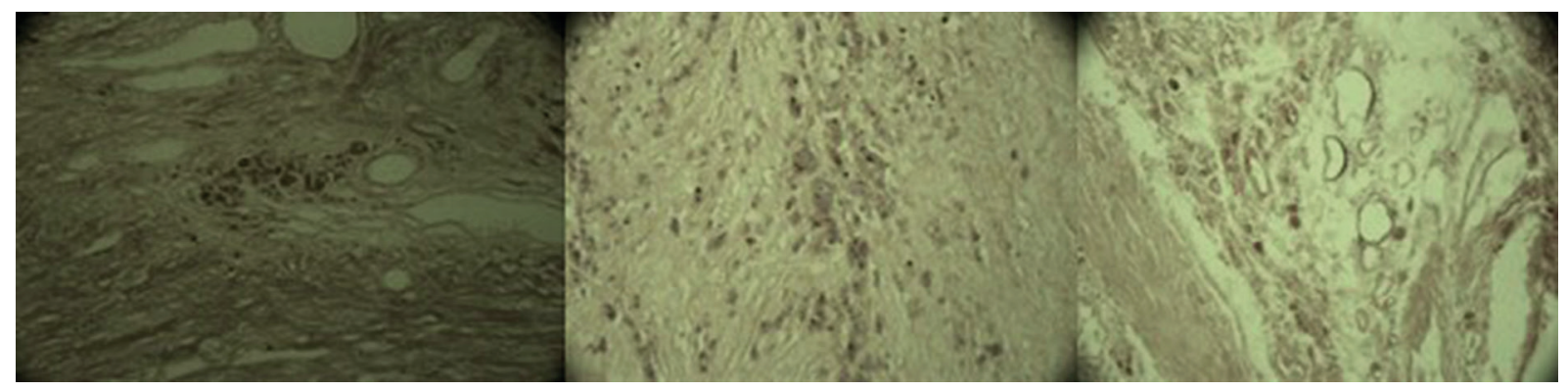

Fig. 4. Immunohistochemical assay with BrdU

outcome are suspected and/or confirmed in clinical retrospective studies [6-8].

According to the thesis that there are differences in myocardial hypertrophy and heart failure between females and males, there is still a strong indication for further investigations also in gender matched and mismatched transplant populations [1].

In the American Heart Association's Scientific Sessions from 2008 the thesis of the importance of gender matching between donors and recipients for short- and long-term survival in heart transplantation was discussed [9]. There was a strong statement that pairing female patients with male donors increases the risk of death during the study. Researchers suggested that heart size and differences in the immune system may explain this correlation. In summary, they stated that: matching donor and recipient by gender resulted in $13 \%$ lower risk of graft rejection within the first year, a $14 \%$ lower rate of graft rejection over the study period, a $25 \%$ drop in the 30 -day death rate and, what is of most importance, a 20\% lower 1-year death rate. Further statistical modeling revealed that the greatest chance for death during the study occurred when pairing a male donor with a female recipient, which made the risk of death an estimated $20 \%$ higher compared to a male donor with a male recipient. The most successful transplants occurred between male recipients and male donors, when the cumulative chance for survival was $61 \%$. They concluded that if equivalent donors exist for a given patient, their data suggest that picking a sex-matched donor may lead to improved short- and long-term survival [9].

The difference between males and females in the area of transplantology is a result of not only the chronic rejection process and vasculopathy. In the aging female heart, hypertrophy, apoptosis and fibrosis are less pronounced that in the male heart of the same age [1]. One of the strongest mechanisms of the failing female heart is down- 
regulation of energy metabolism. There are other mechanisms in heart hypertrophy and failure that differ between female and male hearts. One of them is calcium handling as well as calcium re-uptake and protective function of $17 \beta$-estradiol (E2) against calcium loading induced by hypoxia. There is also increased availability of nitric oxide affected by estrogens in women compared with men, which contributes to better endothelial dependent vasodilatation and increased diastolic distensibility of the heart. The data also suggest differences in pathophysiological mechanisms related to cardiac fibrosis. The sex steroid hormones such as estrogens and testosterone also affect multiple synergistic pathways in the cardiovascular system and influence myocardial remodeling.

Heterotopic heart transplantation is a repeatable model for studies on the rejection and vasculopathy. The modifications of the Ono and Lindsey method such as induction of aortic insufficiency were previously well described [2, 3]. Unexpectedly, cardiac mass was not preserved fully in working (regurgitant) transplants compared with native heart. Therefore, the hemodynamic workload induced by aortic regurgitation was not a sufficient stimulus for cardiac hypertrophy. However, aortic regurgitation correlates with the stroke volume and contributes to maintenance of ventricular mass. A wide range of cardiac atrophy (34\% to $64 \%$ decrease in weight) has been reported in non-working heterotopic transplants, influenced also by the duration of non-working state, and the hearts with induced aortic regurgitation exhibited significantly less atrophy than did the control transplants. This phenomenon is supposed to depend not only on the changes in sarcomere and metabolic activity, but also on structural protein expression in non-working heart. The influence of different degrees of aortic regurgitation on hemodynamic loads necessary to maintain left ventricle mass must be investigated. But still this is the most frequently used animal model for different protocols of heart transplant research.

Although the results of our research regarding graft survival did not confirm the dependence on gender matching of donors and recipients, we observed differences between the study groups. The difference between the donor and recipient weight, as well as weight of the donor heart for given recipient, was not taken into account because in this model the transplanted heart functions as an arteriovenous fistula rather than a "working" heart and this is supposed not to influence either the graft function or overall animal survival.

Although we didn't confirm the statistical significant influence of gender matching on the degree of vasculopathy and graft survival in 10 weeks follow-up there was an observation pointing to females to be better donors.

\section{Study limitations}

The main limitation of the study is the number of experiments in each subgroup, which could affect the results. Also placing a heart heterotopically in the abdominal posi- tion by itself leads to numerous changes in the graft, which was previously explained. This fact has to be considered in animal models of chronic rejection of the heart.

\section{Conclusions}

Cardiac allograft rejection has been extensively studied and is associated with decreased left ventricular function.

The heterotopic heart transplant model is not a lifesustaining model, and especially in chronic rejection and chronic allograft vasculopathy [10], graft survival does not correlate with animal survival.

The population-based Framingham study suggests that prognosis in women is significantly better than in men in heart failure (men usually develop heart failure at a younger age and have higher heart failure mortality than women) [11]. In the analyses of both ISHLT and UNOS registries, increased mortality in gender-mismatched groups is reported [7]. Although evidence of potential gender matching benefits was not strong enough to outweigh the negative effects of increased time on the waiting list, the risk should be taken into account at the time of organ allocation, and should be integrated in the decision-making process, which may have an influence on post-transplant survival.

\section{Disclosure}

The authors report no conflict of interest.

\section{References}

1. Regitz-Zagrosek V, Oertelt-Prigione S, Seeland U, Hetzer R. Sex and gender differences in myocardial hypertrophy and heart failure. Circ J 2010; 74: 1265 1273.

2. Spencer AU, Hart JP, Cabreriza SE, Rabkin DG, Weinberg AD, Spotnitz HM Aortic regurgitation in the heterotopic rat heart transplant: effect on ventricular remodeling and diastolic function. J Heart Lung Transplant 2003; 22: 937-945.

3. Ono K, Lindsey ES. Improved technique of heart transplantation in rats J Thorac Cardiovasc Surg 1969; 57: 225-229.

4. Martins PNA. Assessment of Graft Function in Rodent Models of Heart Transplantation. Wiley Online Library https://doi.org/10.1002/micr.20544.

5. Gordon CR, Matthews MS, Lefebvre DR, Strande LF, Marra SW, Guglielmi M, Hollenberg SM, Hewitt CW. A new modified technique for heterotopic femoral heart transplantation in rats. J Surg Res 2007; 139: 157-163.

6. Eifert S, Kofler S, Nickel T, Horster S, Bigdeli AK, Beiras-Fernandez A, Meiser B, Kaczmarek I. Gender-based analysis of outcome after heart transplantation. Exp Clin Transplantat 2012; 10: 368-374.

7. Bergenfeldt H, Stehlik S, Höglund P, Andersson B, Nilsson J. Donor-recipient size matching and mortality in heart transplantation: influence of body mass index and gender. J Heart Lung Transplant 2017; 36: 940-947.

8. Weiss ES, Allen JG, Patel ND, Russell SD, Baumgartner WA, Shah AS, Conte JV. The impact of donor-recipient sex matching on survival after orthotopic heart transplantation: analysis of 18000 transplants in the modern era. Circ Heart Fail 2009; 2: 401-408.

9. American Heart Association. Gender Matching Aids Long-term Survival After Heart Transplants. Science - Daily. ScienceDaily. Available at: www.sciencedaily.com/releases/2008/11/081112113551.htm.

10. Takami H, Backer CL, Crawford SE, Zales VR, Mavroudis C. Influence of gender on allograft rejection in a rat heart transplant model. J Heart Lung Transplant 1995; 14: 529-536.

11. Ho KK, Anderson KM, Kannel WB, Grossman W, Levy D. Survival after the onset of congestive heart failure in Framingham Heart Study subjects. Circulation 1993; 88: 107-115. 